\title{
ON THE FON ASTROPLATE PROJECT ACCOMPLISHMENT
}

\author{
V.M. Andruk ${ }^{1}$, L.K. Pakuliak ${ }^{1}$, I. Eglitis ${ }^{2}$, Q. Yuldoshev ${ }^{3}$, A. Mullo-Abdolov ${ }^{4}$, \\ S.V. Shatokhina ${ }^{1}$, O.M. Yizhakevych ${ }^{1}$, Yu.I. Protsyuk ${ }^{5}$, H. Relke ${ }^{6}$, V.S. Akhmetov ${ }^{7}$, \\ M.M. Muminov ${ }^{8}$, Sh.A. Ehgamberdiev ${ }^{3}$, G. Kokhirova ${ }^{4}$ \\ ${ }^{1}$ Main Astronomical Observatory of National Academy of Sciences, \\ 27 Akad. Zabolotnogo St., 03143, Kyiv, Ukraine, andruk@mao.kiev.ua \\ ${ }^{2}$ Institute of Astronomy, University of Latvia, \\ Boulv. Rainis 19. LV-1586 Riga, Latvia, ilgmars.eglitis@lu.lv \\ ${ }^{3}$ Ulugh Beg Astronomical Institute of the Uzbekistan Academy of Sciences, \\ 33 Astronomicheskaya str., 100052 Tashkent, Uzbekistan, q.astrin@gmail.com \\ ${ }^{3}$ Research Institute Mykolaiv Astronomical Observatory, \\ 1 Observatorna Str., 54000, Mykolaiv, Ukraine, yuri@nao.nikolaev.ua \\ ${ }^{4}$ Institute of Astrophysics of the Academy of Sciences of Republic Tajikistan, \\ 22 Bukhoro Street, 734042 Dushanbe, Tajikistan, aziz.sherzod@gmail.com \\ ${ }^{5}$ Research Institute Mykolaiv Astronomical Observatory, \\ 1 Observatorna Str., 54000 Mykolaiv, Ukraine, yuri@nao.nikolaev.ua \\ ${ }^{6}$ Walter-Hohmann-Observatory, \\ 159 Wallneyer St., 45133 Essen, Germany, helena_relke@yahoo.com \\ ${ }^{7}$ Institute of Astronomy of V. N. Karazin KNU, \\ 4 Svobody Sq., 61022 Ukraine Kharkiv, Ukraine, akhmetovvs@ gmail.com \\ ${ }^{8}$ Andijan State University, 129 Universitetskaya St., \\ 170100 Andijan, Uzbekistan, muminov1951@gmail.com
}

\begin{abstract}
The plan of the photographic survey of the northern sky (FON) was proposed in 1976 in Golosiiv observatory (now MAO NAS of Ukraine) by I. Kolchinsky and A. Onegina. The final project of the Compiled FONAC catalog (FON Astrographic Catalog) is based on the digital data of photographic plates exposed at four observatories. They are MAO NAS of Ukraine (Kyiv, Ukraine), Kitab astronomical observatory (Tashkent, Uzbekistan), Hissar astronomical observatory (Dushanbe, Tajikistan), and Baldone observatory (Latvia)). The total amount of plates is 5700. The result is expected to be the catalog of positions and B-magnitudes of stars covered the declination area from -20 to 90 degrees. The estimated mean epoch of the catalog is $\sim 1987$. The limiting B-magnitude is $\sim 17.5^{\mathrm{m}}$. The reference system for positions is Tycho-2. B-magnitudes are being obtained in the system of photoelectric standards. The resulted data of photometric reduction are corrected for the photometric color equation in B magnitudes. The complement for the photometric content of the catalog is $U$ and $\mathrm{V}$ magnitudes of stars being obtained from the processing of 5400 plates from the glass collection of $1.2 \mathrm{~m}$ Schmidt telescope in Baldone. Photometric data of bright stars with $\mathrm{V}<8.5^{\mathrm{m}} \mathrm{U}, \mathrm{B}, \mathrm{V}$ magnitudes cannot be obtained from photographic material, so those objects will gain photometric data from photoelectric catalogs. The catalog will be complemented with proper motions from GAIA.
\end{abstract}

Keywords: stellar catalog, digitized plate processing, photometry, UBV system
АНОТАЦІЯ. План фотозйомки північного неба (ФОН) був запропонований у 1976 році в Голосіївській обсерваторії (нині МАО НАН України) І. Колчинським та А. Онєгіною. Остаточний проект каталогу складеного FONAC (FON Astrographic Catalog) грунтується на цифрових даних фотопластинок, експонованих у чотирьох обсерваторіях: МАО НАН України (Київ, Україна), Кітабська астрономічна обсерваторія (Ташкент, Узбекистан), Гіссарська астрономічна обсерваторія (Душанбе, Таджикистан) та Балдонська обсерваторія (Латвія). Загальна кількість пластинок - 5700. В результаті повинен бути створений каталог положень і Ввеличин зірок, який охоплюватиме область неба від -20 до 90 градусів DEC. Орієнтовна середня епоха каталогу - 1987 рік. Гранична В-величина становить $\sim 17,5^{\mathrm{m}}$. Опорною системою є Тусhо-2. В-величини визначаються у системі фотоелектричних стандартів. Отримані дані фотометричної редукції коригуються за фотометричне рівняння кольору у величинах В. Доповненням для фотометричного вмісту каталогу є величини $\mathrm{U}$ та $\mathrm{V}$ зірок, отримані при обробці 5400 пластинок 1,2 м телескопа Шмідта в Балдоне. Фотометричні дані яскравих зірок з величиною $\mathrm{V}<8,5^{\mathrm{m}} \mathrm{U}, \mathrm{B}, \mathrm{V}$ не можуть бути визначені з фотоматеріалу, тому ці об'єкти отримуватимуть фотометричні дані з фотоелектричних каталогів. Каталог буде доповнений власними рухами з GAIA.

Ключові слова: зоряні каталоги, обробка оцифрованих зображень, фотометрія, система UBV 


\section{Introduction}

The plan of the photographic survey of the northern sky (FON) was proposed in 1976 in Golosiiv observatory (now Main astronomical observatory NAS of Ukraine) by I.G.Kolchinsky and A.B.Onegina (Kolchinsky \& Onegina, 1977). The idea arose after the acquisition of Carl Zeiss wideangle astrographs of the same type with aperture $40 \mathrm{~cm}$ and focal length 2 or $3 \mathrm{~m}$ by 6 observatories of the former USSR.

They are Main Astronomical (Golosiiv) observatory of Ukraine, Zvenigorod observatory of Russia, Hissar observatory of Tadjikistan, Abastumani observatory of Georgia, Zelenchuk observatory of Russia and Kitab observatory of Uzbekistan (Pakuliak et al., 2016). Systematic observations of FON project had started in 1982 and lasted until 2000. Unfortunately, the initial idea of four-fold overlapping of the whole northern sky wasn't realized completely. In the final realization of the Compiled FON catalog, we involve wide-angle plates exposed in 3 observatories of Kyiv, Kitab, and Dushanbe. Since 2016, plates of $1.2 \mathrm{~m}$ Schmidt telescope of Baldone observatory obtained in $\mathrm{U}$ and $\mathrm{V}$ color bands were got involved into the project to enhance the photometric part of the catalog (Eglitis et al., 2017; 2018). In MAO NAS of Ukraine FON project is carried out in the framework of UkrVO project (Vavilova et al., 2012ab; 2016; 2017).

\section{Components of the FON Compiled catalog}

1. On the basis of data of 2260 digitized plates from the glass collection of Double Wide-angle Astrograph (DWA) MAO NAS of Ukraine the catalog of positions and Bmagnitudes of objects in the zone DE from -4 to +90 degrees was created (Andruk et al., 2015; 2016ab). Digitizing of astronegatives was carried out using two commercial scanners Microtek ScanMaker 9800XL TMA and Epson Expression 10000XL with 1200 dpi resolution. Linear dimensions of most of the plates were $30 \times 30 \mathrm{sm}$, and digital images are of 13000x13000 pixels (Protsyuk et al., 2014).
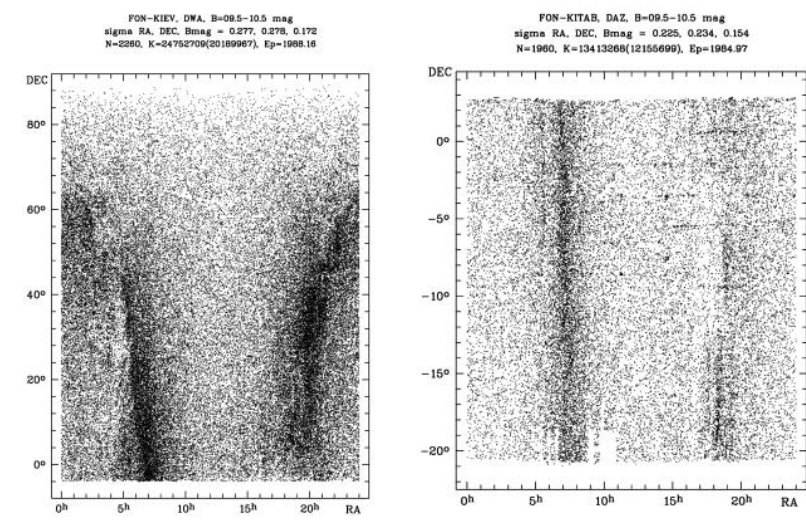

Figure 1: FON-Kyiv star map containing stars of $10^{\mathrm{m}}$ (left) and the sky map of FON-Kitab catalog (right)

The catalog includes 24.7 million stars and galaxies brighter than $\mathrm{B} \leq 16.5^{\mathrm{m}}$ for the mean epoch 1988.2. The reference frame for positions is Tycho-2, and Bmagnitudes were obtained in the system of photoelectric standards. The internal accuracy of the catalog for all objects is $\sigma_{\mathrm{RA}, \mathrm{DE}}= \pm 0.28^{\prime \prime}$ and $\sigma_{\mathrm{B}}= \pm 0.17^{\mathrm{m}}$. For stars with $\mathrm{B}$ $=7^{\mathrm{m}}-14^{\mathrm{m}}$ these errors are $\sigma_{\mathrm{RA}, \mathrm{DE}}= \pm 0.13$ " and $\sigma_{\mathrm{B}}=$ $\pm 0.08^{\mathrm{m}}$. The convergence between calculated and reference positional data is $\sigma_{\mathrm{RA}, \mathrm{DE}}= \pm 0.06$ ", the convergence of photometric data with photoelectric B-magnitudes is $\sigma_{\mathrm{B}}=$ $\pm 0.14^{\mathrm{m}}$. Fig.1, the left panel, shows the FON-Kyiv star map containing stars of $10^{\mathrm{m}}$

2. The Kitab part of FON project has been finished in the zone of DE from -20.5 to +2.5 degrees. The catalog of positions and B-magnitudes of 13.4 million objects brighter than $\mathrm{B} \leq 17.5^{\mathrm{m}}$ for the mean epoch 1985.0 has been created from the digital data of 1963 plates processing (Yuldoshev, 2016, Yuldoshev, 2017a; Yuldoshev, 2017b). Digitizing of astronegatives was carried out using commercial scanner Epson Expression 10000XL. Parameters of digitization, linear dimensions of plates, positional and photometric reference systems are the same as in FON-Kyiv case. The internal accuracy for all objects of the catalog is $\sigma_{\mathrm{RA}, \mathrm{DE}}= \pm 0.23^{\prime \prime}$ and $\sigma_{\mathrm{B}}= \pm 0.15^{\mathrm{m}}$. For objects in the magnitude interval from $7^{\mathrm{m}}$ to $14^{\mathrm{m}}$ these errors are $\sigma_{\mathrm{RA}, \mathrm{DE}}= \pm 0.085^{\prime \prime}$ and $\sigma_{\mathrm{B}}= \pm 0.054^{\mathrm{m}}$. The convergence between calculated and reference positions is $\sigma_{\mathrm{RA}, \mathrm{DE}}=$ \pm 0.042 ", the convergence between calculated B magnitudes and photoelectric reference data is $\sigma_{\mathrm{B}}= \pm 0.16^{\mathrm{m}}$.

Fig.1, the right panel, shows the FON-Kitab star map built for $10^{\mathrm{m}}$ stars.

3. Kyiv and Kitab parts of the FON catalog have the overlapping zone on the declination from -4 to +2.5 degrees. The compiled catalog was created after the crossidentification of common objects. This catalog contains 36.7 million stars and galaxies for the mean epoch 1987.0. For objects, encountered two or more times positional errors are $\sigma_{\mathrm{AC}, \mathrm{DE}}= \pm 0.26^{\prime \prime}$ and photometric ones $\sigma_{\mathrm{B}}=$ $\pm 0.17^{\mathrm{m}}$. For stars in the range $\mathrm{B}=7^{\mathrm{m}}-14^{\mathrm{m}}$ these errors are $\sigma_{\mathrm{AC}, \mathrm{DE}}= \pm 0.120^{\prime \prime}$ and $\sigma_{\mathrm{B}}= \pm 0.072^{\mathrm{m}}$ (Andruk, 2017a).

4. The FON glass collection of Institute for astrophysics of Academy of Sciences of Republic Tajikistan located in Dushanbe includes 1560 plates (Mullo-Abdolov, 2017). The digitizing of plates has been performed using the commercial scanner model Microtek ScanMaker 1000XL Plus. The preceding tests of the scanner gave the errors of star image center estimation $\sigma_{\mathrm{xy}}= \pm 0.054 \mathrm{px}$. Both errors are given for stars brighter than $B=13.5^{\mathrm{m}}$. The insertion errors of scanner in photometric estimations has been found $\sigma_{\mathrm{m}}= \pm 0.020^{\mathrm{m}}$. The first results of processing 71 plates from the collection in the zero declination zone and 58 plates from the declination zones $64,68,72$ give the positional accuracy $\sigma_{\mathrm{RA}, \mathrm{DE}}=0.33$ " for stars in the magnitude range $5^{\mathrm{m}}$ to $17^{\mathrm{m}}$. The photometric accuracy has occurred to be $\sigma_{\mathrm{B}}=0.12^{\mathrm{m}}$. The convergence between calculated and Tycho 2 reference positions of objects is $\sigma_{\mathrm{AC}, \mathrm{DE}}=$ $0.12^{\prime \prime}$, while photometric one is $\sigma_{\mathrm{BT}}=0.19^{\mathrm{m}}$. The convergence with photoelectric data is $\sigma_{\mathrm{B}}=0.14^{\mathrm{m}}$ (MulloAbdolov, 2018).

5. The photometric content of the Compiled catalog can be supplemented with data in two other color bands $\mathrm{V}$ and $\mathrm{U}$. For this purpose, photographic plates obtained with $1.2 \mathrm{~m}$ Schmidt telescope in the observatory of Baldone are being involved (Eglitis, 2018). Baldone collection numbers $780 \mathrm{U}$ and $4660 \mathrm{~V}$ plates. The processing procedures for them are the same as for wide-angle FON plate collection. Plates were digitized using Epson Expression 10000XL commercial scanner. The preceding tests of the 
scanner were made by comparing digitized images of grey 8-bit and 16-bit color depth to assess the accuracy which could be achieved (Eglitis, 2017). The results have shown the instrumental system errors of $\pm 0.0026 \mathrm{px}$ and $\pm .0024^{\mathrm{m}}$ for rectangular coordinates and magnitudes respectively. For the assessment of positional and photometric errors of the scanner, six consequent images of the same plate with 1200 dpi resolution were processed and compared. The scanner errors obtained for stars brighter $13.5^{\mathrm{m}}$ in U-band are $\sigma_{x y}= \pm 0.021 \div 0.027 \mathrm{px}$ and $\sigma_{m}= \pm 0.014^{\mathrm{m}} \div 0.016^{\mathrm{m}}$ for positions and instrumental magnitudes respectively.

\section{Photometric determinations from plate images with two exposures}

Wide-angle observational material of FON project was obtained with two exposures of different durations shifted by both coordinates. The aim was to restore the characteristic curve for photometric determinations as a compiled one from two exposures in order to achieve the same accuracy for stars on the entire range of magnitudes.

Fig. 2 shows the characteristic curves $\mathbf{1}$ and $\mathbf{2}$ for long (20 minutes) and short (20 seconds) expositions of the plate from FON collection (DWA, Kyiv) (Andruk, 2012). On the a-panel, there is the connection of diameters of star images f1 of the long exposure given in respect to the short one f2. The b-panel presents the connection of diameters of two exposures f1, $\mathbf{f} 2$ and photoelectric magnitudes $\mathrm{B}_{\mathrm{pe}}$. The c-panel shows the connection of instrumental magnitudes $\mathbf{m} \mathbf{1}$ and $\mathbf{m} \mathbf{2}$ of both exposures. On the $\mathbf{d}-$ panel, there are characteristic curves for two expositions. The f-panel demonstrates the combined characteristic curve. The combined characteristic curve 1' has been obtained by shifting the characteristic curve of short exposure 2 by $\Delta \mathrm{B}$ in order to continue the long exposition curve 1 to the region of faint and extremely faint stars with $\mathrm{B}>13^{\mathrm{m}}$. In practice, the curve $\mathbf{1}^{\prime}$ has been used for determination of photographic $B_{\text {ph }}$ magnitudes of objects registered on all 2260 negatives of FON collection.

\section{Photometry from plate images with a single exposure}

The photographic material of Baldone Schmidt telescope was obtained with a single exposition. Fig. 3 presents the example of the characteristic curve from the Baldone digitized astronegative and the errors of its restoration.

The errors are given as the differences between calculated U-magnitudes and their photoelectric counterparts $\mathrm{U}_{\mathrm{pe}}$ versus rectangular coordinates $\mathrm{X}$ and $\mathrm{Y}$, the distance from the plate center $\mathrm{R}$, a color index $\mathrm{B}-\mathrm{V}$, and photoelectric magnitudes $\mathrm{U}_{\text {pe }}$.

\section{The photometric system of the catalog}

FON observational material was exposed by telescopes-refractors. Due to this, the results of the photometric processing of digitized plates comprise a color equation. The letter means that obtained photographic magnitudes $\mathrm{B}_{\mathrm{ph}}$ are burdened by systematic errors (corrections) depended on the B-V color index of the star. We used characteristic curves calibrated by reference stars with photo-
DWA, FON, Plate N0001
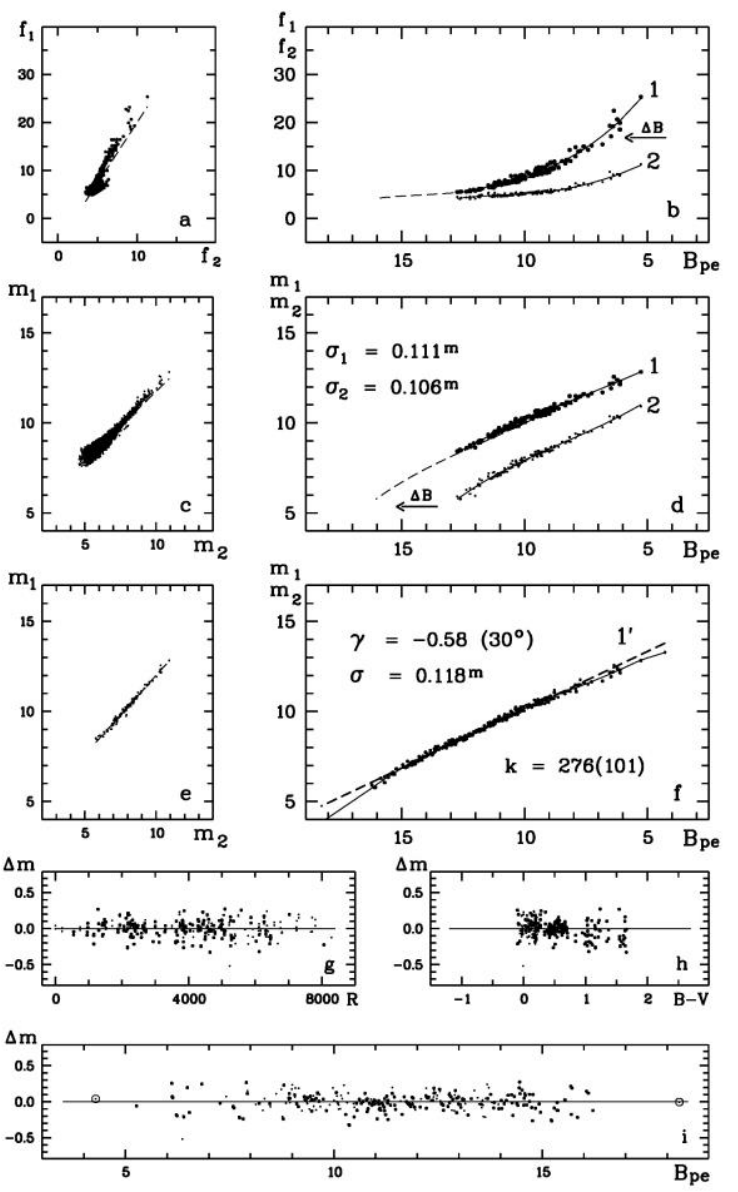

Figure 2: Photometry of stars from plates with two exposures
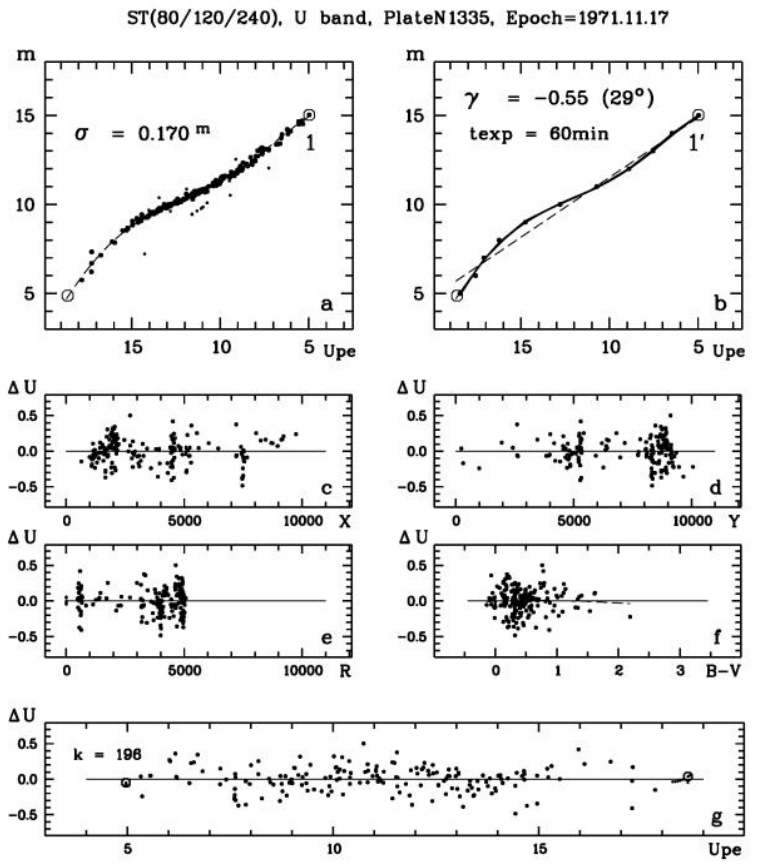

Figure 3: Photometry of stars from plates with a single exposures 

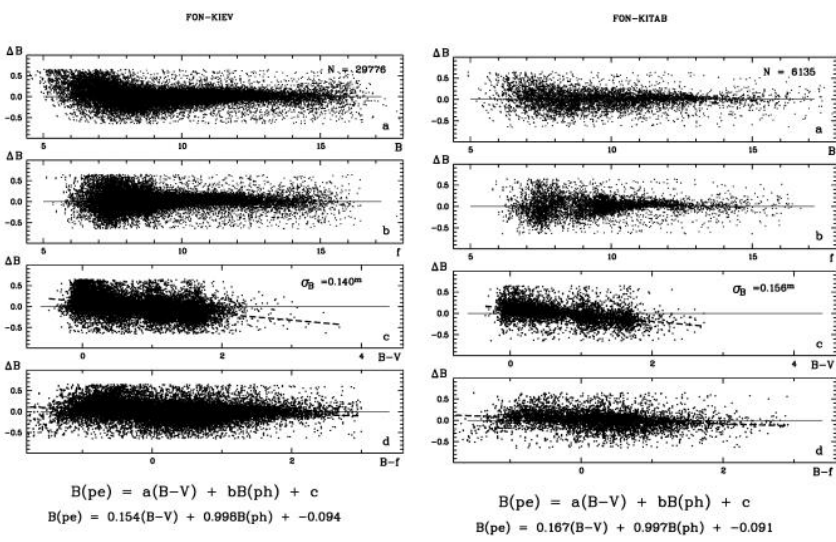

Figure 4: Photometric systems of FON-Kyiv (left) and FON-Kitab(right) catalogs

electric values in order to derive photographic magnitudes $\mathrm{B}_{\text {ph }}$ (Kornilov, 1991; Mermilliod, 1991, Andruk, 1995; Relke, 2015, Andruk, 2017). The results of the comparison of photometric differences $\Delta B=B_{p h}-B_{p e}$ for calculated and reference stars are given in Fig. 4.

Panels $\mathbf{a}$ and $\mathbf{c}$ show the trend of differences $\Delta \mathrm{B}$ relative to $B_{\text {pe }}$ for Kyiv and Kitab parts of FON catalog. Panels $\mathbf{b}$ and $\mathbf{d}$ give the dependences of $\Delta \mathrm{B}$ on photoelectric data $\mathrm{B}-\mathrm{V}$. The numbers of compared stars for parts of the catalog are 29776 and 6135. Rms errors $\sigma_{m}$ of magnitude differences are $\pm 0.140^{\mathrm{m}}$ and $\pm 0.156^{\mathrm{m}}$ respectively. Panels c and $\mathbf{d}$ for Kitab demonstrate the conspicuous color equation with the value of $0.16(\mathrm{~B}-\mathrm{V})$ of star magnitude.

\section{Final steps}

The completive steps of catalog compilation include the completion of Dushanbe FON part digitizing and processing, the completion of the Baldone UV collection digitizing and processing, the completion of photometric content enhancement and correction.

In publications (Akhmetov, 2016; Akhmetov et al., 2018; Protsyuk et al., 2016) the results of the comparison of three obtained (FON-Kiev, FON-Kitab) or being created (FON-Dushanbe) catalogs are given. The estimation of random accuracy of stars positions from the mentioned catalogs was performed by the Wielen method (Wielen, 1995). Final dispersions were calculated for every subrange of magnitudes. The results of the comparison of mentioned catalogs with PMA (Akhmetov et al., 2017), XPM (Fedorov, 2009), UCAC4 (Zacharias et al., 2013), PPMXL (Roeser et al., 2010) are represented in corresponding publications. The external accuracy of stars position of catalogs of FON project is in a good agreement with their internal accuracy and equal from 50 and 300 mas for brightest and faintest stars correspondingly.

The software devised for the processing of Kyiv and Kitab FON plates was successfully tested on the plates with images of Solar system bodies resulted in catalogs of positions of major planets and their moons, asteroids, and comets (Eglitis et al., 2016ab; Protsyuk et al., 2015b, 2017; Shatokhina et al., 2018, Vavilova et al., 2014, Yizhakevych et al., 2017).

\section{References}

Akhmetov V.S.: 2016, Odessa Astron Publ., 29, 116. Akhmetov V.S. Fedorov P.N., Velichko A.B., Shulga V.M.: 2017, MNRAS, 469, 763.

Akhmetov V.S., Khlamov S.V., Andruk V.M., Protsyuk Yu.I.: 2018, Odessa Astron Publ., 31, 199.
Andruk V., Kharchenko N., Schilbach E. et al.: 1995, AN, 316, 225.

Andruk V.M., Ivanov G.A., Yatsenko A.I. et al.: 2012, Bull. T. Shevchenko Nat. Univ. Kyiv.. Astron. N48, 11.

Andruk V.M., Pakuliak L.K., Golovnia V.V. et al.: 2015, Odessa Astron. Publ., 28, 192.

Andruk V.M., Golovnia V.V., Ivanov G.A. et al.: 2016, Kinem. Phys. Cel. Bodies, 32, N1, 32.

Andruk V.M., Pakuliak L.K., Golovnia V.V. et al.: 2016, Kinem. Phys. Cel. Bodies, 32, N5, 260.

Andruk V., Yuldoshev Q., Eglitis I. et al.: 2017, Odessa Astron. Publ., 30, 159.

Andruk V.M., Pakuliak L.K., Golovnia V.V. et al.: 2017, Science and Innovation, 13, N1, 17.

Eglitis I., Eglite M., Pakuliak L.K. et al.: 2016, Odessa Astron. Publ., 29, 126.

Eglitis, I.; $\quad$ Eglite, M.; Shatokhina, S. V.; Andruk, V. M.2016, Odessa Astron. Publ., 29, 123.

Eglitis I., Andruk V.: 2017, Open Astronomy, 26, N1, 7.

Eglitis I., Eglite V., Andruk V. et al.: 2018, Odessa Astron. Publ., 31, 208.

Fedorov P.N., Akhmetov V.S., Bobylev V.V., Gontcharov G.A.: 2011, MNRAS, 415, 665.

Kolchinsky I.G., Onegina A.B.: 1977, Astrometry and Astrophysics, N33, 11.

Kornilov V.G., Volkov I.M., Zakharov A.I. et al.: 1991, Trudy GAIS, 63, 1.

Mermilliod J.C.: 1991, Online Data Catalog: Homogeneous Means in the UBV System (Mermilliod 1991). URL: http:// adsabs.harvard.edu/cgi-bin/nph-data_query?bibcode $=2006 y$ Cat.2168....OM\&link_type $=D A T A \& d b \_k e y=A S T \& h i g h=$.

Mullo-Abdolov, A.; Kokhirova, G.; Relke, H.; et al.: 2017, Odessa Astron Publ., 30, 186

Mullo-Abdolov A., Relke H., Kokhirova A. et al.: 2018, Odessa Astron Publ., 31, 224

Pakuliak L.K., Andruk V.M., Golovnia V.V. et al.: 2016, Odessa Astron. Publ., 29, 132.

Protsyuk Yu.I., Andruk V.N., Muminov M.M. et al.: 2014, Odessa Astron. Publ., 27, 61.

Protsyuk Yu., Relke E.: 2016, Odessa Astron. Publ., 29, 144.

Protsyuk Yu.I., Kovylianska O.E., Protsyuk S.V., Yizhakevych O.M. et al.: 2017, Science \&Innovation, 13, N1, 89.

Relke E., Protsyuk Yu.I., Andruk V.M.: 2015, Odessa Astron. Publ., 28, 211.

Roeser S., Demleitner M., Schilbach E.: 2010, AJ, 139, 2440.

Shatokhina S.V., Kazantseva L.V., Yizhakevych O.M., Andruk V.M.: 2018, Kinem. Phys. Cel. Bodies, 34, N5, 270.

Vavilova I.B., Pakulyak L.K., Shlyapnikov A.A. et al.: 2012, Kinem. Phys. Cel. Bodies, 28, N2, 85.

Vavilova I.B., Pakuliak L.K., Protsyuk Yu.I. et al.: 2012, Baltic Ast., 21, N3, 356.

Vavilova I., Golovnya V., Andruk V. et al.: 2014, Odessa Astron. Publ., 27, 65.

Vavilova I.B.: 2016, Odessa Astron. Publ., 29, 109.

Vavilova I.B., Yatskiv Ya.S., Pakuliak L.K. et al.: 2017, Proc. IAU Symposium, Vol. 325, pp. 361-366.

Wielen R.: 1995, A\&A, 302, 613.

Yizhakevych O.M., Andruk V.M., Pakuliak L.K.: 2017, Kinem. Phys. Cel. Bodies, 33, N3, 142.

Yuldoshev Q.X., Muminov M.M., Ehgamberdiev Sh.A. et al.: 2016, Odessa Astron. Publ., 29, 160.

Yuldoshev Q.X., Muminov M.M., Ehgamberdiev Sh.A. et al.: 2017, Odessa Astron. Publ., 30, 205.

Yuldoshev Q.X., Ehgamberdiev Sh.A., Muminov M.M. et al.: 2017, Kinem. Phys. Cel. Bodies, 33, No. 5, 250.

Zacharias et al.: 2013, AJ, 145, 44. 